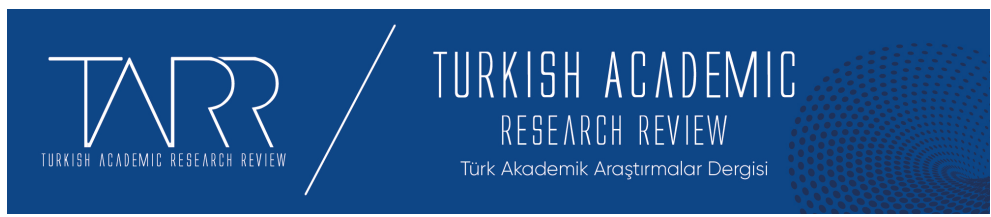

e-ISSN: 2602-2923

Yıl/Year: 2020 Cilt/Volume: 5 Sayı/Issue: 4

The Contemporary Sociology Methods in Turkey: The Analysis of Methodology Debates and Dualities

Türkiye'deki Çağdaş Sosyoloji Metotları: Metodoloji Tartışmaları ve İkilikler Üzerine Bir Analiz

Nuriye Çelik

Assistant Professor, at the Department of Sociology. Faculty of Arts and Science. Sinop University/ Sosyoloji Bölümü, Fen Edebiyat Fakültesi. Sinop Üniversitesi Email: nuriyesenelcelik@gmail.com, Orcid ID: 0000-0001-6368-1956

\begin{tabular}{r|l} 
Makale Bilgisi & Article Information \\
Makale Türü - Article Type & Araştırma Makalesi / Research Article \\
Geliş Tarihi - Date Received & 9 Temmuz / July 2020 \\
Kabul Tarihi - Date Accepted & 26 Aralık / December 2020 \\
Yayın Tarihi - Date Published & 30 Aralık / December 2020 \\
Yayın Sezonu & Ekim - Kasım - Aralık \\
Pub Date Season & October - November - December
\end{tabular}

Atıf / Cite as: Çelik, Nuriye, The Contemporary Sociology Methods in Turkey: The Analysis of Methodology Debates and Dualities/Türkiye'deki Çağdaş Sosyoloji Metotları: Metodoloji Tartışmaları ve İkilikler Üzerine Bir Analiz. tarr: Turkish Academic Research Review, 5 (4), 479-492. doi: 10.30622 tarr.767102.

Intihal / Plagiarism: Bu makale, en az iki hakem tarafindan incelenmiş ve intihal içermediği teyit edilmiştir. / This article has been reviewed by at least two referees and confirmed to include no plagiarism. https://dergipark.org.tr/tr/pub/tarr

Copyright (C) Published by Mehmet ŞAHIN Since 2016- Akdeniz University, Faculty of Theology, Antalya, 07058 Turkey. All rights reserved.

Turkish Academic Research Review - Türk Akademik Araştırmalar Dergisi 


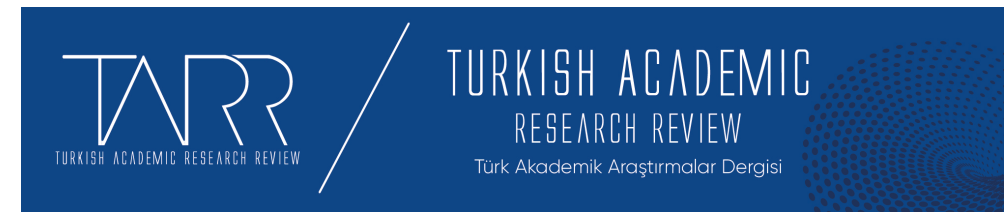

e-ISSN: 2602-2923

Yıl/Year: 2020 Cilt/Volume: 5 Sayı/Issue: 4

\title{
Türkiye'deki Çağdaş Sosyoloji Metotları: Metodoloji Tartışmaları ve İkilikler Üzerine Bir Analiz
}

\author{
Nuriye Çelik
}

Özet

Sosyolojideki metodoloji tartışmaları, sosyolojinin bir bilim olarak doğduğu yıllara kadar dayandırılabilir. Sosyolojinin bir bilim statüsü elde etme çabası ve kurucu sosyologların tanık oldukları toplumsal değişimler, yeni ortaya çıkan sosyoloji biliminin metodolojik tercihlerini de belirlemiştir. Pozitivizimin uzunca bir süre sosyolojideki tek yöntem olarak kabul edilmesi, bu geçmişten beslenmektedir. Tıpkı sosyolojinin doğduğu yılların düzenli bir topluma duyduğu ihtiyaçla bağlantılı olarak şekillenmesi gibi, sosyolojinin metodoloji yöntemleri de artan birey temelli eğilim, toplum- birey ikileminde birey lehine ortaya çıkan toplumsal görüşlerden, modern toplumdaki sorgulamalardan kaynak almakta ve etkilenmektedir. $\mathrm{Bu}$ çalışmanın amacı sosyolojideki metodolojik tartışmalar ile dualitiler arasındaki ilişkiyi ortaya koymak ve metodolojik tercihlerin çağdaş durumunu görmek adına son dönemdeki sosyoloji doktora tezleri ve makaleleri inceleyerek, bu çalışmaların yöntemlerini tartışmaktır. Metodolojideki değişimlerin toplumsal değişimlerle paralel ilerlediği, çağdaş sosyoloji anlayışının mikro temelli teorilere yöneldiği ve buna bağlı olarak sosyolojide son dönem akademik yazında nitel yöntemin daha fazla kullanıldığı tespit edilmiştir. $\mathrm{Bu}$ sonuç metodolojik tartışmaları sonlandırmayacaktır fakat metodolojideki tolumsal değişim etkisini gözlemlemek bakımından önem kazanmaktadır.

Anahtar Kelimeler: Metodoloji, İkililikler, Türkiye Sosyolojisi, Nitel Yöntem, Nicel Yöntem.

\section{The Contemporary Sociology Methods in Turkey: The Analysis of Methodology Debates and Dualities}

\begin{abstract}
The debates on methodology in sociology can be based upon the years when sociology was born as a science. The effort of sociology to achieve a science status and the social changes witnessed by the founding sociologists have determined the methodological preferences of sociology which a new emerging science. Positivism has been accepted as the unique method in sociology for a long time because of that historical roots. Just as the years of the birth of sociology are linked to the need for a regular society, the increasing individual-based tendency in methodology is shaped by the social aspects that arise from a society-individual dilemma in favour of the individual. This study aims to reveal the relationship between methodological debates and dualities in sociology. To be able to see the contemporary status of
\end{abstract}

Turkish Academic Research Review - Türk Akademik Araştırmalar Dergisi 
480 The Contemporary Sociology Methods in Turkey: The Analysis of Methodology Debates and Dualities

methodological preferences, it has examined the methods of sociology doctoral theses and articles written recently. As a result of that study, it was seen that the changes in the methodology have proceeded in parallel with the social changes in society and, contemporary sociology has produced theories based individual and the qualitative method was used more in the recent academic literature in sociology. This conclusion will not end the methodological discussions however, it gains importance in observing the effect of social change in methodology.

Keywords: Methodology, Dualities, Turkish Sociology, Qualitative Methods, Quantitative Methods.

\section{Introduction}

“'How beautiful the world is, and how ugly labyrinths are,' I said relieved.

'How beautiful the world would be

If there were a procedure for moving through labyrinths,'

My master replied.

Umberto Eco, The Name of the Rose (1983:178)"1

The most fundamental question of scientists is what we know, how we access information and how we know it (Della Porta and Keating, 2008:1). Answering this question will lead to a methodological discussion that going back to the time when knowledge was born. The methodology is a method of thinking which provides the opportunity to obtain, question, measure, prove and present the information to others. In that case, the methodology provides us with a roadmap for access to information. Each of the routes on this map is an approach. Approaches "include epistemology or questions about the theory of knowledge; the purposes of research, whether understanding, explanation or normative evaluation; and the 'meta-theories' within which particular theories are located" (Della Porta and Keating, 2008:1). In sociology field, "a theory is a way to explain different aspects of social interactions and to create testable propositions about society" (Keirns et al., 2013:17). During the foundation period of sociology, the first assumptions about methodology started to be put forward. Grand theories, such as the concept of social solidarity used by Durkheim in his analysis of suicide, analysed major social changes using large scales. On the other hand, dramaturgical analysis developed by Goffman was used to analyse one-to-one relationships at the micro-level. Thus, sociological paradigms such as structural-functionalism, symbolic Interactionism, conflict approach and methodological orientations proposed by these paradigms have emerged. The classical theory, which included the contributions of the founding European theorists of the 19th century and the increasing contribution of American sociologists in the 20th century and the influence of Marx in the 1960s and 70s, with the expanding feminist studies in recent years has been shaped as contemporary sociology.

"The contemporary theories include conflict theory, critical theory, symbolic interaction theory, and social exchange theory. In more recent decades, several additional theoretical perspectives have been elaborated, including, for example, rational choice theory, which

${ }^{1}$ Collins, D. (2005). Organisational change: sociological perspectives. Routledge. 


\begin{abstract}
is closely related to exchange theory, the sociology of emotions, neofunctionalism, general systems theory, structuration theory, sociobiology, and various postmodern perspectives. The continued development of various forms of feminist theory has also been influential in the field" (Johnson, 2008:5).
\end{abstract}

The method debates in the sociology field are as old as the debates on individualism and socialism between Durkheim and Tarde (Çelik, 2018; Niezen, 2015; Vargas et al., 2008). Should sociological problems be analysed through institutional mechanisms that revolve around the individual and emerge from the interactions of individuals (Simmel, 2009; Tarde, 1903), or through norms imposed by the society above the individual (Durkheim, 1982a; Durkheim, 1982b)? Of course, it is not clear as this simple question in methodological perspectives because of some concepts such as the duality of structure or the definition of society or passive individual. Social scientists, who were influential in the emergence of sociology in the 19th century, knew that sociology would become a respected science when they applied the common methodological methods in it. This is the reason why Durkheim strives to separate sociology from philosophy and psychology in the coming years and try to give it a scientific character (Durkheim, 1982b). The first issue to be discussed was the research object of sociology. Founding names such as Marx, Comte, and Durkheim developed structure-oriented sociology theories whose main explanatory variables consist of structural phenomena (Esgin and Özben, 2018:36). In this approach, individual actions are influenced by institutional structures. Other orientations in sociology are agent-oriented approaches that centre on individual actions (Esgin and Özben, 2018:36). In this approach, the individual is the only source that has the meaning of action. As the owner of positivist philosophy and sociological theories, Comte developed a social natural science with explanatory schemes; in the Rules of Sociological Method, Durkheim states that sociology aims to build theories through induction based on the observations made on human behaviour in advance" (Giddens, 2013:159). Thus, the social scientist will examine comparable phenomena and avoid the uncertainty of everyday activities. The sociological method, therefore, refers to an important way of thinking that directly determines the research topic of sociology.

According to Giddens, a sociologist's questions in the research process consist of factual, comparison, development and theoretical processes (2012:112). In this process, if the sociologist thinks such as Durkheim, that society has more rigidity than individual actions and that the social structure is something other than the individual, the methodological path he chooses will include positivist qualities. But sociologists, like Goffman, acknowledge that social interactions are created by individuals who make conscious choices, will remain on a much more individualistic level than a sociologist working on a structure-agent relationship that Giddens calls (2012:145) the duality of structure. Similarly, it is inevitable for a Marxist sociologist to conduct a research process through class relations and conflicts. Social and intellectual changes in the modern world have also influenced sociological methods. In the process of the decline of commodity narratives with the influence of post-modernism, classical grand theories have received their share of criticism. The influence of contemporary sociologists such as Baudrillard, Foucault, and Habermas on the methods is another result of the re-evaluation and questioning of classical narratives. For example, Goffman's "civil inattention" is an important state of interaction that allows modern society to spend its daily life in safety and

Turkish Academic Research Review - Türk Akademik Araştırmalar Dergisi 
482 The Contemporary Sociology Methods in Turkey: The Analysis of Methodology Debates and Dualities

respect, and in contrast to classical sociological theories, micro-level interactions are objects of that study.

We see that methodological differences in sociology exist between qualitative and quantitative methods, similar to the perspectives arising from the duality of structure and agent. This divide is shaped by the position of sociology between humanities and natural sciences. "One is associated with the humanities and aligned to constructivism, logical induction and theory-building in the sense of Berger and Luckmann (1991) or Glaser and Strauss (2017), while other is related, to positivism, deduction and falsification in Popper's (2008) sense" (Schwemmer and Wieczorek, 2018). Thus, methodological distinctions have led to the emergence of different Ecoles of sociology and ontological concerns controlled by different paradigms.

"In the United Kingdom, the so-called paradigm wars of the 1980s put a strong emphasis on qualitative methods that are still present today (Bryman, 2008; Gage, 1989). Another example is found in Germany. Here, the so-called 'Positivismusstreit' of the 1960s was fought between representatives of the paradigms of critical rationalism and critical theory (Adorno, 1987). The outcome led to a deepening divide between scholars applying qualitative and quantitative methods as well as antagonizing views on theory that still exist today (Münch, 2018)" (Schwemmerand Wieczorek, 2018).

The basis of traditional hermeneutics which criticizing the methodological partnership of natural and social sciences and positivist evaluation lies in the concept the understanding developed by Dilthey in 19th century (Kasapoğlu, 1992). Weber, who incorporating causal and semantic explanation into the sociological analysis, as opposed to the subject-object separation of Heidegger and Gadamer, provide an objectivist comment (Kasapoğlu, 1992). When we accept that the subject reproduces and shapes meaning instead of what object separation, we face a tradition of analysis that begins with Giddens and continues with Mead, Blumer, Alfred Schutz, Berger, and Luckmann. According to Kasapoğlu, sociology as a science with multiple paradigms, contain that samples (1992): system and conflict paradigms (Friedrichs 1970); Open system and Closed-System paradigms (Eisenstadt and Curelaru, 1976); Marxist, Freudian, Durkheimian, Weberian, Phenomenological, Ethnomethodological, Symbolic Interactionist and Conflict Theory (Effrat, 1972) and also as the basic sociological paradigms:

a) Social facts (Durkheim)

b) Social definition (Weber)

c) Social behaviour (Skinner)

These paradigms differ from the distinctions between Durkheim's positivist methodology and Weber's hermeneutics and Skinner's behavioural approach. Dilthey's advocacy of social science understanding-based constitutes a philosophical tradition that feeds Weber. Wright Mills's 'Sociological Imagination, Alfred Schutz's Social Phenomenology, Harold Garfinkel's Ethnomethodology and Anthony Giddens' Double Hermeneutic approaches form the basis of contemporary sociological theories (Akın, 2008: 110). 


\section{Methodology in Contemporary Sociological Theories and Dualities}

Structure-agent, structure-interaction, macro-micro, understanding-explanation, qualitative-quantitative dualisms in sociology have been the subject of discussion for a long time and in social sciences for to overcome these dualisms, knowledge, objectivity, ontological, epistemological and methodological assumptions, positivist and hermeneutic paradigms have started to be discussed (Uluocak, 2016:103). The struggle to overcome these dichotomies has caused some perspectives such as structuring theory, relational sociology, sociological imagination, social phenomenology, ethnomethodology and double hermeneutic.

Positivist sociology, to discover and document the universal causal laws of human behaviour, emphasizes determinist relations about human activism (free will, will and rationality) and positivist sociology science explanations should not contain any logical contradictions and should be consistent with the observed facts (Bayhan, 2016:222). Positivist social science assumes that objective, observable facts are fundamentally separate from ideas, values or theories (Bayhan, 2016:222). Individual-society, structure-agency, action-system, subjective-objective, qualitative-quantitative dualities determine the differences between positivism and hermeneutic paradigms. Among these dualities meanwhile, society, structure, system, objective and quantitative are the main object and study areas of the positivist paradigm; individual, action, subjective and qualitative are the basic objects and study areas of the hermeneutic paradigm. Based on this differentiation, the following methodological classification can be made:

(a) Methodological Integrity: Research that is within the scope of the positivist paradigm and examines the structure.

(b) Methodological Individualism: Action-based analysis that within the field of study of the Hermeneutic paradigm.

(c) Methodological Relationality: New approaches that transcend the onedimensional review process and investigating structure and action (Ritzer and Stepnisky, 2014:691, as cited in Bayhan, 2016:222-3).

The method changes in sociology are a product of the changes that modern sociology has undergone. It is necessary to look at the space of sociology in the contemporary period in detail. What is the function of sociology in societies today, societies are constantly changing, what about the sociology? How does sociology adapt to the analysis of societies that change so rapidly? Is sociology sufficient to analyze the problems of modern societies and to produce solutions? According to the paper which is based on the keynote address presented by Mark S. Mizruchi, at the 2016 Annual Meeting of the Michigan Sociological Association (2017:1):

"During a time when sociology programs at many colleges and universities are shrinking, we want to look forward. What should/could we be studying? What should we be including in our academic programs to make sociology more relevant to all levels of students and decision-makers? What about businesses or governments? Can [I] put [my] finger on why undergraduate degrees

Turkish Academic Research Review - Türk Akademik Araştırmalar Dergisi 
484 The Contemporary Sociology Methods in Turkey: The Analysis of Methodology Debates and Dualities

in sociology are looked down upon but those in marketing or planning

are not?"

The criticism that American sociology has lost its function belongs to Mizruchi. Mizruchi has considered the job opportunity in the first place among the reasons for the decreasing interest of students toward sociology, then he has mentioned the methodological diversities, and he has demanded from sociologists that be more willing to take alternative viewpoints seriously, and to be willing to face evidence that did not fit deeply their worldviews (2017:24). By the way, how is the methodological diversity and approach to different views among sociologists in Turkey?

\section{Classification of Methods in Sociology Field in Turkish Literature}

Sociology in Turkey arises as modernization, the pains of modernization and prescribing about how we modernize (Akpolat, 2016:4). Similar to the way sociology was created to find a solution for the social crises and post-revolutionary uncertainties in the 19th century, the entrance of sociology in Turkey has coincided with the founding of the New Republic, therefore, it witnessed the construction process of a new nation and state tradition. In institutionalized sociology concept in Turkey, especially in Ziya Gökalp sociology, Durkheim-Comte French sociology is effective (Erbaş, 2015; Çelebi, 2008). It is for this reason that Gökalp is a sociologist who is not a data-oriented but idea-oriented, and the mission of creating a modern nation society has been introduced by him (Çelebi, 2008). II. Mahmut, in 1826, has made real the comprehensive reforms in the field of law, education, administration, bureaucracy, and even communication tools and so on. As a result, a new bureaucrat intellectual class emerged (Bulut, 2014:3). The desire to establish a society and a state-organized according to the positive philosophy has arisen during this period (Bulut, 2014:3). Young Turks are interested in sociology because of two things: they thought the best way to express their views is sociology and also, they believed that science which can penetrate every field, should be involved in management (Bulut, 2014:5). As a result, two important founding names emerged within them: Ziya Gökalp and Prince Sabahaddin.

The first sociology program in Turkey is Istanbul University Literature Faculty and after the republic is the Faculty of Language, History and Geography sociology programs (Erbaş, 2015).At that time in Turkey, there is Istanbul Ecole which includes the understanding of sociology based on more theoretical debates, is not oriented to concrete, is not separated from history and there is Ankara Ecole, although not very influential, that shaped by the influence of the French Frederic Le Play and Prince Sabahaddin and it is non-theoretical and oriented to field research(Erbaş,2015:8;Bulut, 2014; Akpolat, 2007:17). Prince Sabahaddin is the second most important sociologist in Turkey and he focuses his attention on social life, not on models (Çelebi,2008).He similarly Gökalp, plans to use the sociological knowledge for the resolution of the issue of Turkey's salvation and they both study in a macro-sociological way(Çelebi,2008).Arriving in Istanbul in December 1933 as an asylum seeker professor, Kessler presented a community-centric, data-oriented and policy-oriented, practical, mezzo-scale image of sociology (Çelebi,2008). 
"In the 1940s, Behice Boran and Niyazi Berkes began to research Anatolian villages and established a macro-scale, communitycentered, data-oriented studies. As can be seen in the books of Tahir Çağatay and Hans Freyer in the 1950s, the teaching of sociology has transformed into a theoretical education way. In the 1960s, Boran's student Mübeccel Kıray and Kıray's student Emre Kongar have developed a socio-centered, data-oriented, macro-scale sociology. The most popular research technique of this period is the survey method. Sociologists became more interested in micro issues in the 1980s. Women, family, gender role attitudes, media, domestic violence, environment, street children, entrepreneurship, everyday life, old age, suicide researches are rapidly spreading in 10 years until the 1990s. The discussions on the history of sociology and the discussions of epistemology and methodology increased in the 21 st century" (Çelebi, 2008).

Some opinions are accusing Ziya Gökalp about to imitate the Western sociologists and claiming that Turkish sociology imitates Western sociology instead of producing something new (Kaçmazoğlu, 2003:74, as cited in Çağan, 2007:70). These criticisms can be repeated in the field of the method, and it can be claimed that the choice of method is determined by the influence of Western sociology. Besides, it should not be forgotten that the subject and method preferences in sociology are affected by the changes in the society where the sociologist lives. Baykan Sezer (1993) explained his views on the method of sociology in his book, Method Discussions in Sociology. According to him, what Turkish sociology should do is try to determine both national sociology perspectives and its method correctly. He also believes that there is a difference between Western sociology and Turkish sociology (Çağan, 2007:75). Due to a nationalist-conservative understanding of modernization in the 1970 s, it was seen that İbrahim Kafesoğlu, Mehmet Kaplan, Erol Güngör, Cemil Meriç criticized the Turkish revolutions in the Turkish Literature Journal and they formulated an ideology of Turkish-Islamic synthesis (Akpolat, 2006:23). Also, Korkut Tuna (1991) draws attention to the east-west distinction in the analysis made with the concepts imported from the west.

Parallel to the economic, social and political changes in the world in the 1980s, criticism of modernism, individualism, Frankfurt School, postmodernism discourses began to find a place in sociology. The 1980 military coup in 1983 and the transition to a free-market economy is rapidly pushing Turkey into the global economic dynamics, and also in connection with globalization, Turkish sociology begins to fill the conceptual toolbox with translations of postmodern and poststructuralist sociology that has just developed in the West (Akpolat, 2006:24).

Therefore, it can be summarized the development of Turkish sociology in the historical process, as a positivist approach starting with the notion of the founder, a philosophical and theoretical background, Macro-scale field research, which has been influenced by American sociology and a sociological tendency towards micro issues in the last period. The methodology debates in sociology also coincide with this last period. The literature of sociology in Turkey, there are studies mentions the concept of objectivity in sociology (Öztürk, 2017;), focus on methodological

Turkish Academic Research Review - Türk Akademik Araştırmalar Dergisi 
486 The Contemporary Sociology Methods in Turkey: The Analysis of Methodology Debates and Dualities

distinctions and multiple paradigms in sociology (Kasapoğlu, 1992; Alkan, 2015; Çetintaş, 2015; Akın, 2008), and taking attention to methodological dualities and values (Aksan, 2016). According to Çelebi, the object of sociologists is sometimes society, sometimes politics, nation, and state (2008:71). Therefore, the sociologist may be an intellectual who makes theoretical production or a civil servant who produces policies and tries to change society. Başak (2005), who examined the structure debates in sociology, mentioned positive effects of the Turkish sociologists' study in various sub-disciplines and claimed that the theoretical approach that dominates Turkish sociology in structural researches is that Marxist and structural-functionalist approaches are within the scope of positivist paradigm.

"The sole purpose of sociology is not based on given formulas or standardized scientific practices or not to reach certain data, stereotypes about society. The task of sociology is not become social engineering to provide recipes for social problems for satisfying the expectations. In a very clear and simple way, sociology, like other scientific disciplines, is obliged to disclose the reality (social) that is often hidden behind what is visible" (Esgin, 2018:194).

Therefore, the chosen methods and topics should serve this purpose. Positivism, which began with the British empiricist Francis Bacon, entered sociology in a period when Newtonian science prevailed in philosophy, with Simon and Comte's approach to separating science from philosophy and metaphysics (Y1ldizand Hira, 2010:138). "The purpose of the positivist science paradigm is to know for making control and the subjugation of nature." (Bayhan, 2016:218). The method of Turkey sociology has chosen as a positivist and founder due to that period. On the other hand, the method selection is a kind of production of sociologist's social perception. Gouldner and Sprehe in a study made with sociologists in the 60 s. revealed that 27.6 percent of the sociologist once thought to be a priest (2015:42). It can observable the founder sociologists in Turkey, as well as being a scientist, they are a follower of some kind of political ideology. It can observable the founder sociologists in Turkey, as well as being a scientist, they are a follower of some kind of political ideology. Similar to the academician-ideologist portrait seen in Ziyaeddin Fahri Fındıkoğlu and Ziya Gökalp (Bulut, 2014:10), and as Esgin (2015) pointed out, we can claim that there is a conservative tendency behind the need for the social engineering and the need to correct society. A sociologist is not an ordinary scientist, but with several sacred duties, seen as an important person through a distinct political identity. But with changing social and political perceptions, the method of examining social phenomena has also changed and this sanctified duty was partially drawn into the field of science. In a methodological field where, grand theories or peremptory discourses are rejected, the sociologist is the only scientist.

"Turkish society structure, dynamics, and problems; was examined for a long time in Turkish sociology, under the influence of the modernist paradigm; based on rural-urban, traditional-modern contrasts; and by gives a central place the ideal of being a modern like a Western society. Within the framework of this approach, in which the social goal aimed to be achieved is centred, social events were 
tried to be understood and interpreted through the perspective of rulers or sovereigns and sovereign politics" (Bulut, 2014:15).

The criticism that Western sociology lost its functionality in the last period due to lack of solutions to social problems, roots from the fact the dominant influence of American sociology on the world of sociology produced (Gouldner, 2015: 40). We can't easily say that the Sociology produced in Turkey provides cures for social problems in the country. Because the relationship between academics and their willing about field studies, and their political stances, and their traditionalist attitudes, and stereotyped attitudes towards the society they live in prevents sociology from being a productive, flexible and science that produces solutions to contemporary problems. So, what is the methodological position of sociology in Turkey?

\section{Methodology and Evaluation of Data}

This study aimed to examine the methodology way of sociology in the Turkish academy and to show how it's changed. 332 doctoral theses, 7 journals and 61 articles in sociology have been analysed and classification of their methods has been made. The data obtained will be presented in Figure 1.

Figure 1. The Methodology in Sociology PhD Theses

\begin{tabular}{|l|l|c|l|l|}
\hline Year & Qualitative Method & Quantitative Method & Mixed Method & Total \\
\hline 2019 & 55 & 7 & 9 & 71 \\
\hline 2018 & 68 & 4 & 11 & 83 \\
\hline 2017 & 43 & 9 & 3 & 55 \\
\hline 2016 & 40 & 10 & 10 & 60 \\
\hline 2015 & 46 & 8 & 9 & 63 \\
\hline & $\mathbf{2 5 2}$ & $\mathbf{3 8}$ & $\mathbf{4 2}$ & \\
\hline Total & & & $\mathbf{3 3 2}$ \\
\hline
\end{tabular}

Source: Council of Higher Education Thesis Centre.

Doctoral theses written in the field of sociology are important indicators. Because they are important in terms of presenting the current study topics in the field as they are the works that will be turned into publications in the future. When we look at the studies written by adding the subject of sociology, the following data were obtained:

Figure 2. Areas of the Theses Added Sociology to The Subject Section in 2019

\begin{tabular}{|l|l|l|l|}
\hline & Qualitative & Quantitative & Mix \\
\hline Sociology & 55 & 7 & 9 \\
\hline The Communication Sociology & 10 & 0 & 0 \\
\hline
\end{tabular}

Turkish Academic Research Review - Türk Akademik Araştırmalar Dergisi 
488 The Contemporary Sociology Methods in Turkey: The Analysis of Methodology Debates and Dualities

\begin{tabular}{|c|c|c|c|}
\hline Philosophy and Religious Sciences & 15 & 1 & 1 \\
\hline Anthropology & 4 & 0 & 0 \\
\hline Social Service & 2 & 1 & 1 \\
\hline History & 2 & 1 & 0 \\
\hline $\begin{array}{l}\text { Political Science and Public } \\
\text { Administration }\end{array}$ & 7 & 1 & 0 \\
\hline International Relations & 3 & 0 & 0 \\
\hline Educational Sciences & 3 & 2 & 2 \\
\hline Turkish Language and Literature & 1 & 0 & 0 \\
\hline Foreign Languages & 1 & 0 & 0 \\
\hline $\begin{array}{l}\text { Geography and Environmental } \\
\text { Sciences }\end{array}$ & 1 & 2 & 0 \\
\hline Economy & 1 & 1 & 0 \\
\hline Management & 0 & 3 & 0 \\
\hline Fine Arts & 2 & 0 & 0 \\
\hline Tourism Management & 1 & 1 & 0 \\
\hline Regional Studies & 1 & 0 & 0 \\
\hline TOTAL & 109 & 20 & 13 \\
\hline
\end{tabular}

Source: Council of Higher Education Thesis Centre.

Top of the fields that add sociology to the subject section comes to the philosophical and religious sciences due to the sub-branch of sociology as the sociology of religion. Sociology of communication is one of the areas of contemporary sociology. Therefore, the number of doctoral theses with the subject of sociology of communication was 10 in 2019 and the qualitative method has been preferred. In this table, we can see which other sciences are related to sociology. It is possible to say that the thesis is produced mostly in the sociology of religion and sociology of communication.

Figure 3. Methodology in Sociology Journals

\begin{tabular}{|l|l|l|l|}
\hline The Name of the Journal & $\begin{array}{l}\text { Qualitative } \\
\text { Method }\end{array}$ & $\begin{array}{l}\text { Quantitative } \\
\text { Method }\end{array}$ & Mixed Method \\
\hline Sosyoloji Notları & 3 & 0 & 1 \\
\hline Sosyoloji Dergisi & 4 & 0 & 0 \\
\hline İtimaiyat & 6 & 0 & 0 \\
\hline $\begin{array}{l}\text { HUMANITAS - Uluslararasi } \\
\text { Sosyal Bilimler Dergisi }\end{array}$ & 14 & 1 & 1 \\
\hline
\end{tabular}




\begin{tabular}{|l|l|l|l|}
\hline $\begin{array}{l}\text { Journal of Economy Culture and } \\
\text { Society }\end{array}$ & 13 & 3 & 0 \\
\hline Sosyoloji Araştırmaları Dergisi & 5 & 0 & 0 \\
\hline $\begin{array}{l}\text { Paradoks Ekonomi Sosyoloji ve } \\
\text { Politika Dergisi }\end{array}$ & 9 & 1 & 0 \\
\hline TOTAL & 54 & 5 & 2 \\
\hline
\end{tabular}

Source: DergiPark Academic Journal List about Sociology

In this graph, the articles in the last issues of the journals searched with the word "sociology" were examined and analysis was made in terms of a methodological way. In doing so, it is necessary to point out two cases as a prominent element: Firstly, the journals of the institutes of social sciences of universities are excluded from the scope of the study. The reason of that is these journals publish not only the articles of sociology but also the articles of faculties of education and administrative sciences. It is obtained from our observations that the faculties of economic and administrative sciences articles prefer mostly quantitative methods and the faculties of education use different measurement techniques. The second point is observed is the lack of specific journals such as New Media and Society, Gender and Society, Symbolic Interaction, Social Media + Society, or especially the sociology of communication or gender or there are no some journals in which have the only article uses specific method is published. Unlike foreign literature, which has recently turned to the sociology of emotions, such as Emotions and Society or Emotion, Space and Society, it is observed that there are no publications or articles in interesting areas such as sociology of daily life, sociology of emotions or sociology of communication.

"Instead, given the complexity of the social world and the variety of ways it can be analysed, the different perspectives can be regarded as alternative frameworks, or lenses, through which different aspects or features of the social world may be highlighted. All of the theoretical perspectives to be emphasized in this volume are to be seen as providing important insights into the nature of the social world, but all are limited in the specific features of the social world on which they focus" (Johnson, 2008, s.6).

As a result, the selected study topics in sociology are the way sociologists explain and analyse the world around them. Sociologists in Turkey, like their colleagues in other countries, are primarily affected by the developments in the Western sociology, and then social change in their country. Social changes in his society also shape the sociologist.

\section{Conclusion}

Turkish Academic Research Review - Türk Akademik Araştırmalar Dergisi 
490 The Contemporary Sociology Methods in Turkey: The Analysis of Methodology Debates and Dualities

This study has resulted in a way with the opposite of Schwemmer and Wieczorek's (2018) study and coherent with Başak's (2005) study. As a result of the diversity of the sciences investigating social reality and the obligation that insufficient approaches must suggest new ones (Kasapoğlu, 1992:217), we believe that methods of sociology in Turkey evolved into qualitative methods. According to the data obtained in our study, the positivist method is increasingly being replaced by qualitative methods, ethnographic studies, and in-depth interviews. Because of the understanding of sociology in Turkey should give up the blessing of the grand theories and classics of the founding period, this tendency is accepted as a positive development. Instead of sociologist's questionnaires that convert individuals to numerical data, we believe that the studies, in which a certain period of life of sociologist spent in the research field, will reveal more in-depth data. On the other hand, there may be many factors underlying sociologists' preference for methodology. First of all, the methodology should be chosen according to the subject and sample studied and it should be selected in accordance with the nature of the social phenomenon to be investigated. As Esgin claimed that (2015) the criticism about sociologists stay away from the field in order not to dirty their hands or avoid studying towards any social minority, has some trueness. It is also important to note that bureaucratic processes are an important factor in the motivation of sociologists. For example, when I want to visit the nursing home within the scope of urban sociology with my students, the process required a petition for the ministry, and be asked the ethics committee decisions about our visit and all of that takes a really long time. On the other hand, the academic periods spent by the academician with the question whether he/she is a researcher or a teacher because of the excess of the lessons load on him/her and administrative processes of universities are the determinants of academician's choice of methodology and of course academic success. For all these reasons it is necessary to abandon the centrality of the classics in sociology and the validity and reliability of the methodological methods applied should be questioned from the beginning of every research. We suppose that no method transforms into a sacred and uncritical form by the uses of any renowned sociologist. Keeping discussions of methodology in sociology alive will not to cause questioning whether sociology is a science, but will cause it to withstand scientifically solid foundations that are constantly renewed. The dualities in sociology should be re-considered in every study. We think that contemporary sociological approaches, such as the constructivist approach, solve such dichotomies.

On the other hand, we are social scientists who should have a conscientious duty to offer solutions to social problems. To study social and economic inequalities, to examine the groups excluded from society, analyse the factors that create social cohesion and even addressing environmental issues are the areas where sociologists work frequently in foreign academic literature. Also, to check the methodological trends used, the other studies which including more data and time series will provide more comprehensive information regarding method choice. 


\section{References}

Akın, M. H. (2008). Sosyolojide Yöntem Sorunu Olarak Anlama ve Açıklamanın Sinırları. Selçuk University, Faculty of Arts and Sciences, Journal of Social Sciences, 20, 103-114.

Akpolat, Y. (2016). Türk Sosyolojisi Üzerine Kisa Bir Bakış. Sociology Conferences, 53, 3-27.

Aksan, G. (2016). Max Weber ve Değerler Sosyolojisi: Bir Metodolojik İkilemin Düşündürdükleri. Selcuk University the Journal of Faculty of Literature, 35, 427-446.

Alkan, E. Ö. (2015). Sosyolojide Temel Metodolojik İkilikler ve Bunlari Aşma Girişimleri. Inönü University International Journal of Social Sciences, 4(1), $1-24$.

Başak, S. (2005). Türk Sosyolojisinde Yapı Araştırmaları. Bilig, 32, 33-63.

Bayhan, V. (2016). Sosyal Bilimlerde" Objektiflik" Efsanesi. Mukaddime, 7(2), 217 242.

Bulut, Y. (2014). Türkiye'de Sosyolojinin 100 Y1l. Istanbul University Journal of Sociology, 3(28): 1-21.

Çağan, K. (2007). Türk Sosyolojisi ve Baykan Sezer. Journal of Social Sciences, 9 (2), 69-86.

Çelebi, N. (2008). Sosyoloji Sosyologun Yaptığı İse. Hacettepe University Turkish Studies (HÜTAD), (8), 69-80.

Çelik, N. (2018). Kamusal Alanda Sosyal Taklit: Sosyal Medyada Yeni Gelin Evi Imgesi, Selçuk University, Institute of Social Sciences, Department of Sociology PhD Thesis, Konya.

Çetintaş, A. (2015). Sosyolojik Kuramlara Hakim Temel Paradigmalar Çerçevesinde Toplum-Birey Dualizmi. Inönü University International Journal of Social Sciences, 4(1), 25-42.

Collins, D. (2005). Organisational Change: Sociological Perspectives. Routledge Puplications.

Della Porta, D., and Keating, M. (Eds.). (2008). Approaches and Methodologies in The Social Sciences: A pluralist perspective. Cambridge University Press.

Durkheim E. (1982b) The Contribution of Sociology to Psychology and Philosophy (1909). In: Lukes S. (eds) The Rules of Sociological Method: Contemporary Social Theory. Palgrave, London

Durkheim, E. (1982a). The Method of Sociology (1908). In the Rules of Sociological Method (pp. 245-247). Palgrave, London.

Erbaş, H. (2015). Türkiye'de Bedeller Ödemiş bir Sosyolojik Düşünce Ustası: Sosyolog Behice Boran. Mülkiye Dergisi, 39(3), 5-58.

Turkish Academic Research Review - Türk Akademik Araştırmalar Dergisi 
492 The Contemporary Sociology Methods in Turkey: The Analysis of

Methodology Debates and Dualities

Esgin, A. (2015). Sosyal Bilimci mi, Yoksa Doksalog Teknisyenlermiyiz? Türkiye'deki Bazi Sosyoloji Pratikleri Üzerine Eleştiriler. Sociology Notes, $52(2015-2) / 191-220$.

Esgin, A., Özben, M. (2018). Klasik Sosyoloji ve Gündelik Hayat: Durkheim'dan Parsons'a, in Gündelik Hayat Sosyolojisi, Ed: Ali Esgin, Güney Çeğin, Phoenix Puplications, 13-35.

Giddens, A. (2012). Sosyoloji, Kırmızı Publications, 1. Edition, İstanbul.

Giddens, A. (2013). Sosyolojik Yöntemin Yeni Kurallarl, Sentez Publications, 2. Edition, Ankara.

Gouldner, A. W. (2015). Batı Sosyolojisinin Yaklaşan Krizi. Trans: Mesut Şenol, Sakarya University Culture Publications, Sakarya.

Johnson, D. P. (2008). Contemporary Sociological Theory: An Integrated Multilevel Approach. Springer Science and Business Media.

Kasapoğlu, M. A. (1992). Sosyolojide Birlik Sağlama. Ankara University the Journal of Department of Philosophy, 14, 201-218.

Keirns, N. J., Strayer, E., Griffiths, H., Cody-Rydzewski, S., Scaramuzzo, G., Sadler, T., ... and Jones, F. (2013). Introduction to sociology. OpenStax College, Rice University.

Mizruchi, M. S. (2017). The Current Crisis of American Sociology, Michigan Sociological Review, 31,1-26.

Niezen, R. (2015). The Durkheim-Tarde Debate and the Social Study of Aboriginal Youth Suicide. Transcultural psychiatry, 52(1), 96-114.

Öztürk, E. (2017). Sosyolojide Nesnellik Sorunu Bağlamında Max Weber'in Pozitivizm-Hermeneutik İkiliğini Aşma Girişimi. Ankara University Journal of Social Sciences, 4(1), 196-244.

Schwemmer, C., and Wieczorek, O. (2020). The Methodological Divide of Sociology: Evidence from Two Decades of Journal Publications. Sociology, 54(1), 3-21.

Sezer, B. (1993), Sosyolojide Yöntem Tartışmaları, Sümer Puplications, İstanbul.

Simmel, G. (2009). Bireysellik ve Kültür, çev. Tuncay Birkan, İstanbul: Metis Puplications.

Tarde, Gabriel (1903). The Laws of Imitations. Elsie Clews Parsons (translator), New York: Henry Holtand Company.

Tuna, K. (1991). Türk Sosyolojisinin Batı Sosyolojisi İle İlişkisi ve Sonuçlart: 75. Yılında Türkiye'de Sosyoloji, Edit: İsmail Coşkun, Bağlam Puplications, İstanbul.

Uluocak, Ş. (2016). Tözcülük-İlişkisellik Dikotomisi Açisindan İlişkisel Sosyolojik Modellerin Türkiye'de Sosyoloji Pratiği ve Düşünümselliği Açisindan Olasi Açilimlari. Sosyoloji Konferanslart, (53), 101-153.

Vargas, E. V., Latour, B., Karsenti, B., Aït-Touati, F., and Salmon, L. (2008). The Debate Between Tarde and Durkheim. Environment and Planning D: Society and Space, 26(5), 761-777.

Yıldız, R., and Hira, İ. (2010). Sosyal Bilimlerde Yöntem Tartışmaları Bağlamında Kuhn ve Rothacker. Journal of Academic Studies (AID), 5(2), 133-153. 